\title{
Zakat As An Alternative Revenue and Financing Resources for the State
}

\author{
Ah. Fathonih
}

\begin{abstract}
Zakat As An Alternative Revenue and Financing Resources for the State. Zakat is one of the religious obligations that have social, economic, political, and legal dimensions. The obligation has been effectively practiced by Muslims since the 7th century during the time of the Prophet Muhammad. The amount of zakat in Indonesia is very potential, reaching 217 trillion rupiahs, which can be used to solve the problem of poverty and socio-economic imbalances. Unfortunately, up to now the potential of zakat has not been able to reduce poverty and improve social welfare. The Zakat Management Act Number 23 of 2011 and Number 14 of 2014 concerning the Implementation of the Zakat Management Law only regulates the management of zakat under the supervision of the government. The government can manage zakat productively as a source of state income (non-tax state income) and state funding sources (State Sukuk or State Sharia Securities). This study finds that the difficulties faced by the Indonesian government to manage zakat funds productively are mostly related to people's understanding of zakat as a religious obligation and not as a state obligation. Besides, zakat is mostly used for consumptive and unproductive purposes only.
\end{abstract}

Keywords: zakat management, regulation, revenue, state financing resources.

\begin{abstract}
Abstrak: Zakat Sebagai Pendapatan Alternatif dan Sumber Pembiayaan Untuk Negara. Zakat adalah salah satu kewajiban agama yang memiliki dimensi hukum sosial, ekonomi, dan politik. Kewajiban itu secara efektif telah dipraktikkan oleh Muslim sejak abad ke-7 di masa Nabi Muhammad. Jumlah zakat di Indonesia sangat potensial, mencapai 217 triliun rupiah, yang dapat digunakan untuk menyelesaikan masalah kemiskinan dan ketidakseimbangan sosial ekonomi. Sayangnya, hingga saat ini potensi zakat belum mampu mengurangi angka kemiskinan dan meningkatkan kesejahteraan sosial. Undangundang Pengelolaan Zakat Nomor 23 tahun 2011 dan Nomor 14 tahun 2014 tentang Penerapan UU Pengelolaan Zakat hanya mengatur pengelolaan zakat di bawah pengawasan pemerintah. Padahal, pemerintah dapat mengelola zakat secara produktif sebagai sumber pendapatan negara (pendapatan negara bukan pajak) dan sumber pendanaan negara (Sukuk Negara atau Surat Berharga Syariah Negara). Tulisan ini menunjukkan bahwa kesulitan yang dihadapi oleh pemerintah Indonesia untuk mengelola dana zakat secara produktif sebagian besar terkait dengan pemahaman masyarakat tentang zakat sebagai kewajiban agama dan bukan sebagai kewajiban negara. Selain itu, zakat sebagian besar digunakan hanya untuk tujuan konsumtif dan tidak produktif.
\end{abstract}

Kata Kunci: manajemen zakat, regulasi, sumber daya pendapatan, pembiayaan negara.

Faculty of Sharia and Law, State Islamic University, Sunan Gunung Djati Bandung, West Java, Indonesia Jl. A.H. Nasution No.105, Cipadung, Cibiru, Bandung, West Java, Indonesia 40614

E-mail: ah.fathonih@uinsgd.ac.id 


\section{Introduction}

According to historical account, the implementation of zakat obligation has been effective since the $2^{\text {nd }}$ year of Hijriyah. Besides being as mahdhah fardhiyah (obligatory worship), zakat was also being as mu'âmalah ijtimâ'iyah (social responsibility worship).

Zakat has economic, legal, social, and political dimensions. ${ }^{1}$ As a socio-economic institution, Zakat is the first fiscal system in the world which organizes six elements, namely: the subject of zakat payers (muzakki), assets of zakat (mall al-zakat), respective rates (miqdâr al-zakat), the minimum asset ownership limit (nishâb), the period of ownership of the assets (haul), and the recipients of the zakat fund (mustahiq).

Seeing from the perspective of Islamic legal thought, there are five forms of zakat management in contemporary muslim societies: first, the obligatory zakat collection system enacted by the state; second, compulsory zakat collection carried out by the public or the private sector; third, voluntary collection of zakat by the state; fourth, voluntary collection of zakat by the private sector; and fifth, collecting zakat voluntarily at the individual level without collective management at all. ${ }^{2}$

In it social dimension, zakat cannot be separated from the social life of its people. The size of the Indonesian muslim population is directly proportional to the magnitude of the potential of zakat in the country. The huge potential of zakat in Indonesia is reaching 217 trillion rupiahs. $^{3}$ Thus, it should ideally become a financial solution in overcoming the problems of poverty and socio-economic inequality. ${ }^{4}$ Nonetheless, in

${ }^{1}$ Abu Yusuf, Kitâb Al-Kharaj (Beirut Libanon: Dar al-Mảrifah, 1979), p. 76; Abu Ubaid, Kitab Al-Anwâl (Beirut, Libanon: Dâr al-Kutub al-Ilmiyah, 1986), p. p.23, See also; Abu Hassan al-Mawardi, Al-Ahkâm Al-Sulthâniyah (Egypt: Mustafa al-Babi al-Halaby, 1393), p. 113.

${ }^{2}$ Amelia Fauzia, Faith and the State A History of Islamic Philanthropy in Indonesia (Leiden: Brill Academic Publisher, 2013), p. 175; See also Chusnunia Adib, Peran Negara dalam Pengelolaan Zakat Umat, article at Yuri Sulistyo, Antikowati Antikowati, and Rosita Indrayati, 'Pengawasan Pemerintah Terhadap Produk Hukum Daerah (Peraturan Daerah) Melalui Mekanisme Pembatalan Peraturan Daerah Berdasarkan Undang-Undang Nomor 32 Tahun 2004 Tentang Pemerintahan Daerah', Lentera Hukum, 1.1 (2014), 1-12 <https://doi.org/10.19184/ejlh.v1i1.559>.

${ }^{3}$ Nikmatuniayah Nikmatuniayah and Marliyati Marliyati, 'Akuntabilitas Laporan Keuangan Lembaga Amil Zakat di Kota Semarang', MIMBAR, Jurnal Sosial dan Pembangunan, 31.2 (2015), 485-94 <https://doi.org/10.29313/mimbar.v31i2.1562>.

${ }^{4}$ Amalia Amalia and Kasyful Mahalli, 'Potensi dan Peranan Zakat dalam Mengentaskan 
reality, the huge potential of zakat has not been able to reduce poverty significantly and improve the welfare of the community ${ }^{5}$, which for a small part is still shackled by poverty and underdevelopment.

The huge potential ${ }^{6}$ of zakat in Indonesia is not only become one of the financial instruments that can contribute to state revenues, but also may become one of the country's financings instruments. The idea proposed here is based on the argument that if the zakat is managed systemically and comprehensively, it can be managed productively by the state as a potential source to finance various forms of infrastructure development and drive the economy. To do so, zakat should not only be seen as a source of consumptive funds distributed only to recipients of zakat (mustahiq). ${ }^{7}$

The possibility of making zakat as an alternative instrument of state revenue and financing resources should not be something difficult to do as the provisions for government to regulate zakat are already enacted. They are the Act Number 38 of 1999, the Act Number 23 of 2011, and the Government Regulation Number 14 of 2014. In addition, it is also possible to make the zakat as one of the state financing sources, after converting it into Sharia Government Securities (SBSN) or Sukuk as regulated under the Law of State Budget and Expenditure (APBN).

\section{Zakat Management in the History of Islamic Law}

In the early period of Islam, zakat became a source of state funding and functioned effectively in empowering and building the welfare of the

Kemiskinan di Kota Medan', Ekonomi dan Keuangan, 1.1 (2012) <https://jurnal.usu.ac.id/index. php/edk/article/view/635> [accessed 31 May 2019].

${ }^{5}$ Fakhruddin Fakhruddin, 'Rekonstruksi Paradigma Zakat: Sebuah Ikhtiar Untuk Pemberdayaan Mustahiq', Al-Manahij: Jurnal Kajian Hukum Islam, 6.2 (2012), 229-42 (p. 230) <https://doi.org/10.24090/mnh.v6i2.601>; Alfalisyado Alfalisyado, 'Reformulasi Zakat dan Pola Pribumisasi Hukum Islam Melalui Komunikasi Inter-Cultural', Al-Manahij: Jurnal Kajian Hukum Islam, 7.1 (2013), 89-100 <https://doi.org/10.24090/mnh.v7i1.579>.

${ }^{6}$ Abdul Malik, Arya Hadi Dharmawan, and Titik Sumarti, 'Konstruksi Sosial Kuasa Pengetahuan Zakat: Studi Kasus Lembaga Amil Zakat di Propinsi Jambi dan Sumatera Barat', Sodality: Jurnal Sosiologi Pedesaan, 4.2 (2010), p. 193 <https://doi.org/10.22500/sodality. v4i2.5847>.

7 Yusuf Wibisono, Mengelola Zakat Indonesia: Diskursus Pengelolaan Zakat Nasional dari Rezim Undang-Undang No. 38 Tahun 1999 Ke Rezim Undang-Undang No. 23 Tahun 2011, edisi ke-2 (Jakarta: Prenadamedia Group, 2016), p. 7. 
poor. During the life of the Prophet Muhammad, the period of Khulafa al-Rashidin until the Umayyad and Abbasid Dynasties, the handling of the zakat problem was not left solely to the willingness and awareness of zakat payers, but it became a part of the government responsibility, starting from the process of collection, management, to the distribution of zakat assets.

The government responsibility in the management of zakat has been signaled by the Prophet Muhammad, when he sent Muadz bin Jabal to Yemen. ${ }^{8}$ The officers appointed by the Prophet were provided with operational technical instructions to collect and manage the zakat assets in full trust. In the early days of Islam, zakat was one of the government income sources that was managed and used effectively by the government to develop and to improve economic welfare of the community

Based on the hadith narrated by Ibn Abbas, there is an explanation that the assignment of Muadz bin Jabal to Yemen implied that the implementation of zakat in the Medina period was no longer only left entirely to the consciousness of muslim communities, but the acquisition and distribution of zakat was carried out by the ruling government. Thus, this historical evidence shows that from the beginning of the leadership of the Prophet Muhammad PBUH, zakat was managed by government institutions and the Prophet Muhammad PBUH also appointed the employees to calculate and to collect zakat from the Muslims community. ${ }^{9}$

In another story, the Prophet Muhammad PBUH also once appointed and instructed his best friends Umar ibn Khattab, Ibn Qais, and 'Ubadah ibn Tsamit as amil zakat at the regional level. ${ }^{10}$ They were responsible to foster the residents for paying the obligation of zakat.

${ }^{8}$ Bukhari and Muslim, Al-jâmi' Al-Sholeh Li Al-Bukhâri (Beirut: Dar al-Fikr, 1981), p. 837; and Al-Jâmi' Al-Shohîh Li Al-Muslim, Juz I (Kairo: Mustafa al-Halaby, 1983), p. 327.

9 A. A Miftah, 'Zakat Sebagai Hukum Diyani dan Qada'i dalam Negara Indonesia' (UIN Syarif Hidayatullah, 2005), p. 57; Afzalur Rahman, Islam Ideology and The Way of Life, (Kuala Lumpur: AS Noordeen), p. 118; Saidurrahman Saidurrahman, 'The Politics of Zakat Management in Indonesia: The Tension Between BAZ and LAZ', Journal of Indonesian Islam, 7.2 (2013), 366-382-382 (p. 368) <https://doi.org/10.15642/JIIS.2013.7.2.366-382>.

${ }^{10}$ Faisal Faisal, 'Sejarah Pengelolaan Zakat di Dunia Muslim dan Indonesia (Pendekatan Teori Investigasi-Sejarah Charles Peirce dan Defisit Kebenaran Lieven Boeve)', Analisis: Jurnal Studi Keislaman, 11.2 (2011), 241-72 (p. 247) <https://doi.org/10.42042/analisis.v11i2.612>. 
During the lifetime of the Prophet Muhammad, there were the five types of property which were subject to compulsory zakat, namely money, merchandise, agricultural products, fruits, and spoils (rikâz). ${ }^{11}$ In determining the type of property that must be paid its zakat, the Prophet Muhammad PBUH also provided examples and operational instructions for the administrator of zakat. The operational management of zakat can be seen in the structure of amil, which consists of (1) Katabah, officer who records obligatory zakat; (2) Hâsabah, officer who estimates and calculates zakat; (3) Jubah, an attractive officers who taking zakat from muzakki; (4) Khazânah, an officer who collects and safeguards the assets of zakat; and (5) Qasamah, officers who channel zakat to mustahiq al-zakat. $^{12}$

During the period of Abu Bakr al-Shiddieq (11-13 H./632-634 $\mathrm{AD})$, the implementation of zakat management was carried out through the Chaliph authority by appointing several zakat officers (amil) in the whole of Islamic jurisdictions. All residents who rejected zakat payment are considered as the rebels and opposition of the government. Regarding on this case, the Caliph of Abu Bakr al-Shiddieq took offensive action against them until they agreed to pay zakat. ${ }^{13}$

Regarding the administration of zakat, Abu Bakar practiced his policy following the pattern used by the Prophet Muhammad. He appointed several zakat officers in the whole of Islamic jurisdictions to collect and distribute zakat. Beside founding Bait al-Mâl in the city of Medina, he appointed Abû Ubaidah as his treasurer and gave him the authority to distribute zakat to the Muslims who were entitled to receive it.

During the period of Umar bin Khattab (13-25 H/634-644 AD), the policy of zakat management was still carried out by the Caliph

${ }^{11}$ See QS. 2: 261, QS. 9: 34, QS. 6: 141

${ }^{12}$ Mustafa Edwin Nasution, Pengenalan Ekslusi Ekonomi Islam, (Jakarta: Kencana, 2006), p. 214.

${ }^{13}$ Abu Bakr's statement against the tribes who did not pay zakat with the expression "For Allah's sake, I will fight them who distinguish between the obligation of worship and the obligation to pay zakat, because zakat deals with property. O Allah, if they avoid the obligation of them to pay zakat to me, even though only one child is a goat, which they should have paid to the Messenger of Allah, I will fight them - I will fight them because of that rejection". See Irfan Mahmud Ra'ana, Sistem Ekonomi Pemerintahan Umar Ibn Al-Khattab (Jakarta: Pustaka Firdaus, 1992), p. 87-88. 
authority and always conducted by the âmil zakat officers to oversee the security of the zakat storage warehouse. He did not hesitate to threat a warning and would take firm action against officials who were negligent or misused the zakat assets. Umar appointed Sufyan bin Malik, as the zakat management officer together with Muhammad bin Masalamah. During his reign, the management of zakat expanded progressively which was indicated by the amount of zakat collected and its distribution to the poor. ${ }^{14}$

The Caliph of Umar bin Khattab also set another policy relating to zakat by obliging zakat upon land rent (kharaj) and horses, which had never been happened in the period of the Prophet Muhammad PBUH and the Caliph of Abu Bakar al-Shiddieq. The Caliph of Umar bin Khattab considered to include horse zakat, because, during the reign, horses became trafficked animals and giving many contributions to economic activities. Such was really different with the period of the Prophet Muhammad PBUH and the Caliph of Abu Bakar al-Shiddieq who did not include horses as part of the worshiped unless it was only seen as the animal to be maintained and not to be traded.

During the reign of Usman bin Affan (24-36 H./644-656 AD), the management of zakat also develoved extensively. The Caliph of Usman bin Affan was very well known as one of the best friends of the Prophet who spent almost all of his personal property to the needs of Islam. Usman appointed Zaid ibn Thabit as a special official to handle the zakat management as well as to take care of the government financial institutions (Bait al-Mâl).

During the period of Usman bin Affan, zakat was classified into two types, namely: (1) zakat on the visible property (Zakât al-Amwâl al-Zâhirah) such as livestock and agricultural products; and (2) zakat on the invisible or hidden property (Zakât al-Amwâl al-Bâthiniyyah), such as money and commercial property. The first category of zakat is collected by the government as a form of foreign exchange income for the government and the second category of zakat is given to individuals

${ }^{14}$ Abu Yusuf, p. 82. 
or mustahiq al-zakât, who are obliged to issue their own zakat as a form of self-assessment. ${ }^{15}$

At the last period of Khulafa al-Rashidin, in the period of Ali ibn Abi Thalib (36-41 H./658-661 AD), the application and implementation of zakat also followed the wisdom of his predecessor caliphs. Ali instructed the zakat officers to collect the assets of zakat and distribute them immediately to those who are entitled and really need them. He argued that there is no accumulation of assets of zakat in Bait al-Mâl. He PBUH that zakat is the lifeblood of life for government and religion. In one story he was mentioned "When he took a walk in seeing the condition of his community, he met a group of needy and beggar blind people who were non-Muslim (Christians). Then he ordered the amil zakat at that time, that the cost of their lives must be borne by Bait al-Mâl". The interesting point of this statement was Ali also directly involved in distributing the assets of zakat to all mustahiq. ${ }^{16}$

Similarly, in the following periods, especially in reign of Umar ibn Abd al-Aziz (717-720 AD), The caliph also had great attention to the management of zakat. At the times, he intervened himself in distributing the assets of zakat to those who were entitled to receive it, even delivered it to their respective places. It was during the Caliph of Umar ibn Abd al-Aziz that the zakat management system had begun to advance and be more professional. Umar ibn Abd al-Aziz was a reformer (mujaddid) in the first century ago who obliged zakat on assets obtained from business income or services, including salaries, honorarium, and other various income from the profit of property and assets management (al-mustafad malls ). It was in this time that the types of zakat assets and properties that are subject to zakat were expanded. ${ }^{17}$

Referring to the Prophet Muhammad PBUH practices and which were followed by Khulafa 'al-Rashidin it can be conluded that zakat is

${ }^{15}$ Abu Yusuf, p. 8.

${ }^{16}$ Abdurrahman Qadir, Zakat dalam Dimensi Mahdhah dan Sosial (Jakarta: PT. Raja Grapindo, 1998), p. 94.

${ }^{17}$ Yusuf Qardawi, Fiqh Zakat (Mesir: Maktabah Wahbah1994, 1994), pp. 71-72; Elsa Kartika Sari, Hukum Zakat dan Wakaf (Jakarta: PT. Grasindo, 2007), p. 34. 
not merely a "charitable" form of worship but also it is also a communal obligation. In otherwords, the management of zakat should not only rely on the zakat payers awareness but it also needs communal involvement. Islam has placed the obligation of zakat as part of the government economic policy and legalized it to the zakat law and regulations. The utilization of zakat for poor people is certainly inseparable from the role of the amil zakat institution. He was demanded by the sharia to develop institutional policies relating to the utilization of zakat. As the government institution, the institution of amil zakat certainly should have a legal guarantee.

The position of zakat, thus, is very fundamental and strategic. Zakat has a strategic function in the context of the Islamic economic system and one of the legal instruments to overcome poverty, solve the economic problems, and raise the dignity of the poor people. ${ }^{18}$ Reducing poverty has certain impacts in minimizing crime rate, prostitution, and social conflicts.

\section{Dynamics of Zakat Management Regulation in Indonesia}

Reformation era has indirectly paved a "new way" for renewal of zakat regulation in Indonesia. The birth of the Zakat Law Number 38 of 1999 gave rights to the government to provide maximum services for Muslims in fulfilling the obligations of zakat in accordance with the guidelines of Islamic law. By issuing the law, the government is expected to increase the function and role of zakat to minimize poverty and to maximize socio-economic welfare of the Muslims who are increasingly shackled by poverty and underdevelopment. ${ }^{19}$

${ }^{18}$ Naimah Naimah, 'Konsep Hukum Zakat Sebagai Instrumen dalam Meningkatkan Perekonomian Ummat', Syariah: Jurnal Hukum dan Pemikiran, 14.1 (2014) <https://doi. org/10.18592/syariah.v14i1.66>; Lukman Abiyoso, Darsono Wisadirana, and Solih Mu'adi, 'Peranan Zakat Sebagai Manifestasi Ketaqwaan dalam Penanggulangan Kemiskinan (Studi Implementasi Lembaga Amil Zakat Al-Ittihad Desa Sidowungu Kecamatan Menganti Kabupaten Gresik)', Wacana, Jurnal Sosial dan Humaniora, 18.2 (2015) <https://doi.org/10.21776/ ub.wacana.2015.018.02.1>; Samheri, 'Zakat Produktif Sebagai Titik Tolak Kebangkitan Peradaban Islam | El-Furqania : Jurnal Ushuluddin Dan Ilmu-Ilmu Keislaman' <http://ejournal.kopertais4. or.id/madura/index.php/elfurqania/article/view/880> [accessed 31 May 2019].

${ }^{19}$ Jazuni, Legislasi Hukum Islam di Indonesia, Cet. 1 (Bandung: Citra Aditya Bakti, 2005). 
The existence of the zakat law is driven by internal and external factors. This background of the zakat law is based on philosophical, juridical, and sociological reasons. As the Minister of Religion of the Republic of Indonesia in 1999, A. Malik Fajar, delivered an explanation before the session of the Indonesian People's Representative Council or DPR RI, before the commencement of the session responses from the factions, represented elements of the government. In his description and explanation, he said that the management of zakat in Malaysia and Singapore experiences is a more significant increase than Indonesia, especially after being managed properly by the government regulations.

Some other reasons, he also explained that the existence of the zakat law in Indonesia include several reasons such as: first, the emergence of discourse, which zakat today is no longer a mere discourse of jurisprudence, but it has become the concern of economists; second, in some muslim countries and the majority of the muslim population today, the management of zakat is based on the law instruments that regulated by the government. This can be shown in the form of management that is entirely handled by the government or its management by other zakat institutions that obtained a formal legitimacy by the government. ${ }^{20}$ According to Zysow, ${ }^{21}$ there are currently six muslim countries where zakat is encouraged through laws, namely Saudi Arabia, Libya, Yemen, Malaysia, Pakistan, and Sudan.

The Zakat Law Number 38 of 1999 can be seen as a product of renewal of Islamic law in Indonesia. ${ }^{22}$ The law has institutionally provided a definite basis for the management of zakat to establish organization. Certainly, The organization should be much better than in the past, either in managerial or personal aspects. In addition, the law should

${ }^{20}$ Monzer Kahf, 'Applied Institutional Models for Zakah Collection and Distribution in Islamic Countries and Communities, in Institutional Framework of Zakah; Dimensions and Implications, Ed. Ahmed Abdel-Fattah El-Asker and Muhammad Sirajul Haq' (Jeddah: IRTIIDB, 1995).

${ }^{21}$ A. Zysow, 'Zakāt', Encyclopaedia of Islam, Second Edition, 2012, p. $418<$ <https:// referenceworks.brillonline.com/entries/encyclopaedia-of-islam-2/zakat-COM_1377> [accessed 18 May 2019].

${ }^{22}$ Widyawati, Philanthropy Islam \& Kebijakan Negara Pasca Orde Baru (Bandung: Arsyad Press, 2011). 
also replace old orientation of zakat distribution which mainly to fulfill the consumptive needs of eight asnâf to a more productive utilization without sacrificing the fulfillment of the poor needs.

In terms of the types of assets, the zakat law has surpassed the standard books being referred in pesantren, especially among the Shafi' $i$ school. While the Shâf'i's books pay attention much to the objects of zakat (gold, silver, livestock, plants, fruits, merchandise, mines, rikaz assets, and zakat fitrah) the new law gives a room to extend the object of zakat adapted from a new situation evolving in the society. Last but not least, the regulation also provides a basis to the establishment of Bait al-Mâl, a financial institution which can accommodate Islamic philanthropic funds that stopped in the mid of society.

Along with the passage of time and the growing demands of the community, the zakat management system as regulated in Zakat Law No. $38 / 1999$ is considered to be less than optimal in addressing the problem of zakat in Indonesia. One of the weaknesses is the ambiguity towards which institutions will play the main role in the management of zakat, whether the Amil Zakat Agency (BAZ) or the Amil Zakat Institution (LAZ). ${ }^{23}$ BAZ seems to belong to the government, while LAZ belongs to the community. Because of that weakness, in 2011 the government replaces the old zakat regulation by issuing a new law namely The Zakat Management Law Number 23 of 2011.

The issuance of Zakat Management Law Number 23 of 2011 cannot be separated from the constitutional consideration that the government guarantees the independence of the population to worship according to their religion and to provide statutory regulations to manage the zakat. This law has instituted the sharia norm on zakat as revealed in the Quran and the Sunna in the form of laws in Indonesia. Therefore the obligation to pay zakat for Muslims in Indonesia since the enactment of this law until now has not solely based on religion, but also by the government law. In sociological considerations, the

${ }^{23}$ Iskan Qolbu Lubis, 'Pandangan Umum Fraksi Terhadap Amandemen Undang-Undang Zakat, Anggota Komisi VIII DPR RI Dari Fraksi PKS' (INFOZ Edition 16 Year VI, 2012), p. 4. 
substance of this law has also an important role in realizing public welfare and alleviating poverty.

Meanwhile, we can see it from the background of its birth, this law is also seen as a new breakthrough, where zakat is used as part of national development to improve the function of zakat and also places its institutions in a central position while having the power of formal law. Another big idea of the Zakat Management Law Number 23 of 2011 and the Government Regulation Number 14 of 2014 are regulates the management of zakat in an integrated manner through carried out by BAZNAS (National Amil Zakat Agency) at all levels as well as LAZ (Amil Zakat Institution) which gets legality status according to statutory provisions. Through the integration of zakat management, it is ensured that the potential and realization of zakat collection from all regions and the benefits of zakat for poverty alleviation will be measured for the realization of the management of zakat that must be trustworthy, professional, transparent, accountable and participatory.

The integration of zakat management has also resulted in BAZNAS as the coordinator is one of wealth. The coordination carried out by BAZNAS will oversee the process of integration and synergy from the management side as well as from the side of sharia compliance. Based on this reason, LAZ also becomes part of a system coordinated by BAZNAS, then its position is legally strongest as well as the principles and guidance of Islamic economic values derived from the Quran and the Sunna can be fulfilled practically.

Through the implementation of the principles and guidance of the sharia norms, zakat management is intended to organize the management of zakat much better. It is also addressed to the arrangements of the zakat management and will become amil zakat more professional, have formal legality and follow a system of accountability to the government and society. In this context, amil zakat has the duties and responsibilities to manage zakat professionally based on the awareness that it can be separated from the principles of sharia norms which related to the government authority.

Therefore, the implementation of zakat management regulation is 
necessary to be done by the amil zakat. BAZNAS and LAZ can also work together in one big goal, namely to optimize the collection, distribution, and utilization of zakat funds to improve the economic welfare of the poor people, and state development. Shortly, the improvement of performance, the reporting of flows and the accountability of BAZNAS and LAZ should be a common concern along with social and economic changes in accordance with the regulations changes towards the integration of zakat management in the future.

\section{Zakat as Potential Sources for the State Economic Development}

The management of zakat funds may become an alternative solution to overcome the high poverty rate, to provide the welfare for the poor, and to establish the fulfillment of justice and economic equality. It is a very strategic policy for the government to optimize the economic development as it was exemplified by the Prophet Muhammad PBUH and his Companions in early Islam. Today, this also becomes the attention of the government of Indonesia to explore the function of zakat as a strategic way and potential sources for economic development. In this context, the government also needs to rebuild and reinforce a system of law and procedures on how to collect the zakat assets effectively and managed it comprehensively to become one of the state financial instruments. Through this strategy, the zakat may be expected to give benefits for alleviating poverty and elevating the ranks of the poor in a society, including making it as a top priority for economic development.

According to Kusuma, ${ }^{24}$ zakat can be used as one of the instruments of fiscal policy and financing for the state. Besides, it is also can be used to improve the country's economy, especially if the portion is quite significant to increase the Gross National Product (GDP). Therefore, there are three steps to carried out the optimization of the utility of zakat,

${ }^{24}$ Kusuma, Dimas Bagus Wiranata, and Raditya Sukmana, 'The Power of Zakah in Poverty Alleviation' (Presented at the Seventh International Conference - The Tawhidi Epistemology: Zakat and Waqf Economy, Bangil, 2010); Also see Mustafa Edwin Nasution, 'Zakat dan Wakaf Sebagai Pilar dalam Sistem Perekonomian Nasional', Iqtishoduna, 1.3 (2006) <https://doi.org/10.18860/ iq.v1i3.205>. 
namely: (1) calculating the number of poor people who are entitled to zakat based on the characteristics of previously stated; (2), analyzing the funding needed to provide a minimum standard of life; and (3), calculating the potential of zakat that can be collected and compare it with existing needs.

Asnaeni ${ }^{25}$ point out several factors that become obstacles in managing the zakat professionally: first, lack of knowledge and public awareness. There are few muzakki fulfiling the zakat obligation and paying zakat mâl to the formal zakat institutions such as the National Zakat Agency (BAZNAS) and the Amil Zakat Institution (LAZ); second, the lack of the government's role in carrying out its duties and functions in accordance with the Zakat Management Law; third, the lack of socialization, both structurally (conducted by the formal zakat institutions) and nonstructurally (conducted by da'i/da'iyah and public); and fourth, zakat management has not been fully focused to develop economy.

Based on the four factors mentioned above, the management of zakat can be maximized through several strategies namely: first, the role of muzakki. Muzakkis understanding is very important in optimizing zakat and using it as an economic source for the state. People has to be given a clear understanding that the obligation of zakat is not only a part of figh but also a public duty formally regulated by the government in the form of Zakat Management Law. Thus, a new interpretation is needed to reinterpret the figh of zakat to be more applicable and relevant with the socio-economic condition without contradicting it with the universal principles in the Quran, the Sunna, and the Ulama's Consensus (al-Ijmâ).

A study on the development of zakat shows that zakat is possible to be explored as a productive asset to develop state economy. In Islamic philanthropy, zakat consists of various types of assets including benefits from various business activities. In terms of zakat object (mahall al-zakât), Zakat is not only seen as worship (ta'abbudi) but also a part of social worship (mâliyah). A number of verses in the Qur'an concerning to

${ }^{25}$ Asnaini Asnaini, 'Membangun Zakat Sebagai Upaya Membangun Masyarakat', La_Riba, 4.1 (2010), p. 19-33 <https://doi.org/10.20885/lariba.vol4.iss1.art2>. 
this matter can be reinterpreted in accordance with the socio-economic development. This reason is based on these arguments: first, the global texts listed in the Quran emphasize that in every wealth attaches the right of others; second, all rich people need to cleanse and purify their wealth; third, the Prophet Muhammad PBUH as well as his companions used the zakat assets to increase the development of economy. Although in the classical period of Islam, various assets had not been subject to zakat, but in the contemporary period, all assets can be imposed to zakat obligation. Thus, the realization of this awareness now depends on the commitment of the muslim scholars, academicians, policy makers, authorities to extend the zakat as a source of state economic development.

In an economic perspective, there are dimensions of zakat. First, the capital. Various researchers have tried to calculate the potential of national zakat. In 1989, Monzer Kahf conducted a research which he found that the potential of national zakat can reach 2\% of total GDP. It means that the potential of zakat is not less than 100 trillion rupiahs. In 2001 the National Amil Zakat Agency (BAZNAS) and the Faculty of Economics and Management of IPB conducted reseach on similar topic and found that the potential of zakat reached $3.40 \%$ of GDP or not less than 217 trillion rupiahs. second, social justice. Zakat can improve social justice in the community; third, social equilibrium, the social balance can be built by the distribution of zakat and makes the poor people get a share from a part of them; fourth, social guarantee. The community feels guaranteed when zakat can be realized in its form, which the poor people are not worried to seek treatment or obtain educational services due to the absence of security bills; fifth, social safety. The large accumulation of zakat funds also becomes beneficial assets and standby funds for unexpected events like natural disasters, monetary crisis, etc.

In a sociological perspective, the distribution of zakat should be focused on helping poor people to improve their life. The institutions of zakat should be managed the zakat assets from consumptive to productive. For instance, $50 \%$ of the zakat assets collected by the BAZNAS or LAZ can be distributed to poor people in the form of business financing. They can spend the money resulted from zakat financing as a basic capital to 
increase their economic activities together with his or her colleagues in a big or small group of people. To encounter the fraud case, of course, it must be practically supervised and monitor by the BAZNAS or LAZ.

Then in political perspective, the role of the government in taking policies on zakat management is also needed to enforce the distribution zakat effectively. One of the responsibilities of the government role to maintain the zakat distribution for the poor people and those who are physically weak is to regulate and legalize the zakat management under the government role. No one else or institution can collect zakat free without controlled by the government. In this case, the government has to undertake a policy as the main policy maker in optimizing the zakat management through maximizing its duties and roles.

On the one hand, the existence of the Zakat Management Law Number 23 of 2011 has also placed the government as a regulator. The regulation is becoming quite capable of blowing fresh air of the zakat management in Indonesia. Furthermore, it should be more effective when the government regulated the Zakat Management Law Number 23 of 2011 and the Government Regulation Number 14 of 2014 on the Implementation of Zakat Management Law Number 23 of 2011, even though on the other hand these regulations are not strictly implemented. According to some Muslim legal scholars, the Law Number 23 of 2011 becomes the legal instrument for the zakat management in Indonesia, even though there are still some weaknesses from the structure, substance, material, and implementation aspects. However, it has currently placed the government as a regulator to optimize the potential of zakat funds in the future.

A recommendation of zakat as an alternative to revenue and financing sources for the state is based on the reason that the potential of zakat funds is very large and beneficial as one of the sources for income and financing for the state. There are two advantages such as besides being a source of the state income, it is also useful to sustain infrastructure development economically. The government does not always dependent on foreign debt loans. In this context, zakat can also be managed by the government productively and profitably when it used as a source of the 
state funding through State Sukuk or State Sharia Securities (SBSN) as stipulated in the State Budget Law (APBN Law).

In the Indonesia legal system, it is explained that the APBN Law covers three components, namely the income budget, expenditure budget, and financing budget. The income budget can be obtained from taxes and not taxes. In this context, zakat can be one of the state revenues derived from non-tax sectors. For the components of the financing budget, the government generally only relies on financing from abroad and does not yet maximize domestic financing. On this side, zakat can be a source of domestic financing framed in State Sukuk or State Sharia Securities (SBSN).

Finally, the amount of potential zakat in Indonesia is very possible to be one source of income and financing for the state. Indonesia can conduct comparative studies with other Muslim countries which first make zakat as a source of income and financing for the state. In addition, the government must encourage people to contribute to paying zakat and also buy Government Securities as part of a collective effort to improve the country's economic development. Without the shared awareness of all citizens and the role of the government, these efforts become something in vain.

\section{Conclusion}

Referring to the description and analysis, it can be concluded that the existence of Zakat Management Law Number 23 of 2011 and Number 14 of 2014 are limited to regulate the procedures for zakat management under the government supervision. These regulations are very limited to fulfill the formal lawsuits regarding on zakat management rules, but these have not a positive impact to the country's economic development, guaranteeing law enforcement, disciplining muslims in carrying out the zakat obligation, and improving the economic welfare for the poor people in Indonesia. Even though the potential of zakat funds in Indonesia is very large and possible to be used as a source of revenue and financing for the state, it has not fully implemented in practice.

The biggest difficulty that may be faced by the Indonesian government 
today and in the future is that most people only understand zakat as a religious obligation and not as a state obligation. In addition, zakat is mostly used only for consumptive and has not been managed productively, both individually and institutionally. There are two solutions that can be done by the state to manage zakat productively which is to make it as a source of state income (non-tax state income) and state funding sources (State Sukuk or State Sharia Securities).

\section{Bibliography}

Abiyoso, Lukman, Darsono Wisadirana, and Solih Mu'adi, 'Peranan Zakat Sebagai Manifestasi Ketaqwaan dalam Penanggulangan Kemiskinan (Studi Implementasi Lembaga Amil Zakat Al-Ittihad Desa Sidowungu Kecamatan Menganti Kabupaten Gresik)', WACANA, Jurnal Sosial dan Humaniora, 18.2 (2015) <https://doi. org/10.21776/ub.wacana.2015.018.02.1>

Abu Ubaid. Kitâb Al-Anwâl. Beirut, Libanon: Dar al-Kutub al-Ilmiyah, 1986.

Abu Yusuf. Kitûb Al-Kharaj. Beirut, Libanon: Dar al-Ma’rifah, 1979.

Al-Mawardi, Abu Hassan. Al-Ahkâm Al-Sulthâniyah. Egypt: Mustafa alBabi al-Halaby, 1393.

Alfalisyado, Alfalisyado, 'Reformulasi Zakat dan Pola Pribumisasi Hukum Islam Melalui Komunikasi Inter-Cultural', Al-Manahij: Jurnal Kajian Hukum Islam, 7.1 (2013), p. 89-100 <https://doi.org/10.24090/ mnh.v7i1.579>

Amalia, Amalia, and Kasyful Mahalli, 'Potensi dan Peranan Zakat dalam Mengentaskan Kemiskinan di Kota Medan', Ekonomi dan Keuangan, 1.1 (2012) <https://jurnal.usu.ac.id/index.php/edk/article/view/635> [accessed 31 May 2019]

Asnaini, Asnaini, 'Membangun Zakat Sebagai Upaya Membangun Masyarakat', La_Riba, 4.1 (2010), 19-33 <https://doi.org/10.20885/ lariba.vol4.iss1.art2>

Bukhori, and Muslim, Al-Jâmi' Al-Sholeh Li Al-Bukhari. Beirut: Dar al-Fikr, 1981. 
Faisal, Faisal, 'Sejarah Pengelolaan Zakat di Dunia Muslim dan Indonesia (Pendekatan Teori Investigasi-Sejarah Charles Peirce dan Defisit Kebenaran Lieven Boeve)', Analisis: Jurnal Studi Keislaman, 11.2 (2011), p. 241-72 <https://doi.org/10.42042/analisis.v11i2.612>.

Fakhruddin, Fakhruddin, 'Rekonstruksi Paradigma Zakat: Sebuah Ikhtiar Untuk Pemberdayaan Mustahiq', Al-Manahij: Jurnal Kajian Hukum Islam, 6.2 (2012), p. 229-42 <https://doi.org/10.24090/mnh.v6i2.601>. Fauzia, Amelia. Faith and the State A History of Islamic Philanthropy in Indonesia. Leiden: Brill Academic Publisher, 2013.

Jaih Mubarok, et.all, 'Tim Pengkajian Hukum Tentang Pengelolaan Zakat Oleh Negara Bagi Kesejahteraan Masyarakat'. Jakarta: BPHN Departemen Hukum dan HAM RI., 2011.

Jazuni, Legislasi Hukum Islam di Indonesia, Cet. 1. Bandung: Citra Aditya Bakti, 2005.

Kusuma, Dimas Bagus Wiranata, and Raditya Sukmana, 'The Power of Zakah in Poverty Alleviation'. Presented at the Seventh International Conference - The Tawhidi Epistemology: Zakat and Waqf Economy, Bangil, 2010.

Kahf, Monzer. 'Applied Institutional Models for Zakah Collection and Distribution in Islamic Countries and Communities, in Institutional Framework of Zakah; Dimensions and Implications, Ed. Ahmed Abdel-Fattah El-Asker and Muhammad Sirajul Haq'. Jeddah: IRTIIDB, 1995.

Kurniawan, Puji. Legislasi Undang-Undang Zakat. Jakarta: Tintamas, 2009. Lubis, Iskan Qolbu. 'Pandangan Umum Fraksi Terhadap Amandemen Undang-Undang Zakat,Anggota Komisi VIII DPR RI Dari Fraksi PKS’ (INFOZ Edition 16 Year VI, 2012)

Malik, Abdul, Arya Hadi Dharmawan, and Titik Sumarti, 'Konstruksi Sosial Kuasa Pengetahuan Zakat: Studi Kasus Lembaga Amil Zakat di Propinsi Jambi dan Sumatera Barat', Sodality: Jurnal Sosiologi Pedesaan, 4.2 (2010) <https://doi.org/10.22500/sodality.v4i2.5847> Miftah, A.A., 'Zakat Sebagai Hukum Diyani dan Qada'i dalam Negara Indonesia'. UIN Syarif Hidayatullah, 2005. 
Nasution, Mustafa Edwin. Pengenalan Ekslusi Ekonomi Islam. Jakarta: Kencana, 2006.

. 'Zakat dan Wakaf Sebagai Pilar dalam Sistem Perekonomian Nasional', Iqtishoduna, 1.3 (2006) <https://doi.org/10.18860/ iq.v1i3.205>

Naimah, Naimah, 'Konsep Hukum Zakat Sebagai Instrumen dalam Meningkatkan Perekonomian Ummat', Syariah: Jurnal Hukum dan Pemikiran, 14.1 (2014) <https://doi.org/10.18592/syariah.v14i1.66> Nikmatuniayah, Nikmatuniayah, and Marliyati Marliyati, 'Akuntabilitas Laporan Keuangan Lembaga Amil Zakat di Kota Semarang', MIMBAR, Jurnal Sosial dan Pembangunan, 31.2 (2015), p. 485-94 $<$ https://doi.org/10.29313/mimbar.v31i2.1562>

Qardawi, Yusuf. Fiqh Zakat. Mesir: Maktabah Wahbah1994.

Qadir, Abdurrahman. Zakat dalam Dimensi Mahdhah dan Sosial. Jakarta: PT. Raja Grapindo, 1998.

Ra'ana, Irfan Mahmud. Sistem Ekonomi Pemerintahan Umar Ibn AlKhattab. Jakarta: Pustaka FIrdaus, 1992.

Rahman, Afzalur. Islam Ideologi and The Way of Life. Kuala Lumpur: AS Noordeen.

Saidurrahman, Saidurrahman, 'The Politics of Zakat Management In Indonesia: The Tension Between BAZ and LAZ', Journal of Indonesian Islam, 7.2 (2013), p. 366-382-382 <https://doi.org/10.15642/ JIIS.2013.7.2.366-382>

Samheri. 'Zakat Produktif Sebagai Titik Tolak Kebangkitan Peradaban Islam | El-Furqania : Jurnal Ushuluddin dan Ilmu-Ilmu Keislaman' <http://ejournal.kopertais4.or.id/madura/index.php/elfurqania/article/ view/880> [accessed 31 May 2019].

Sari, Elsa Kartika. Hukum Zakat dan Wakaf. Jakarta: PT. Grasindo, 2007. Sulistyo, Yuri, Antikowati Antikowati, and Rosita Indrayati, 'Pengawasan Pemerintah Terhadap Produk Hukum Daerah (Peraturan Daerah) Melalui Mekanisme Pembatalan Peraturan Daerah Berdasarkan UndangUndang Nomor 32 Tahun 2004 Tentang Pemerintahan Daerah', Lentera Hukum, 1.1 (2014), p. 1-12 <https://doi.org/10.19184/ejlh.vli1.559> 
Wibisono, Yusuf. Mengelola Zakat Indonesia: Diskursus Pengelolaan Zakat Nasional Dari Rezim Undang-Undang No. 38 Tahun 1999 Ke Rezim Undang-Undang No. 23 Tahun 2011, edisi ke-2. Jakarta: Prenadamedia Group, 2016.

Zysow, A., 'Zakāt', Encyclopaedia of Islam, Second Edition, $2012<\mathrm{https} / /$ referenceworks.brillonline.com/entries/encyclopaedia-of-islam-2/ zakat-COM_1377> [accessed 18 May 2019] 